Jurnal Pena Sains Vol. 7, No. 1, April, 2020

p-ISSN: 2407-2311

e-ISSN: 2527-7634

\title{
EFFECTIVENESS OF COMICS ON STUDENT LEARNING OUTCOMES
}

\author{
Ruqiah Ganda Putri Panjaitan ${ }^{1}$, Kurnia Ningsih ${ }^{2}$, Novi ${ }^{3}$ \\ 1,2,3 Prorgam Studi Pendidikan Biologi, Fakultas Keguruan dan Ilmu Pendidikan, Universitas Tanjungpura \\ Pontianak, 78115, Indonesia \\ ruqiah.gpp@fkip.untan.ac.id ${ }^{1}$, kurnia.ningsih@fkip.untan.ac.id ${ }^{2}$, novi.fbio@gmail.com $^{3}$
}

DOI: $10.21107 / j p s . v 7 i 1.6377$

\begin{abstract}
This study aimed to determine the effectiveness of comics on students' learning outcomes. The research population is students of eight grades. This research is a quasi-experimental design with a nonequivalent control group design. The determination of the research sample used the intact group technique. The average of students' learning outcomes in the experimental class, which is using comic is 15.29 while the control class, which is using PowerPoint is 11.90 , and the value of effect size is 1.56 . The learning by using comics is sufficient to increase the students' learning outcomes.
\end{abstract}

Keywords: Learning outcomes, Circulatory system, Comic

\footnotetext{
${ }^{1}$ Corresponding Author
} 


\section{Introduction}

The national education system is the entire education component connected to the achievement of national education goals. The components of the national education system in question are the objectives, students, teachers, and education personnel (Yusuf, 2018; Munirah, 2015). The goal of education can be achieved with maximum if there is a development of ability and character formation to build the intelligence of the nation (Ministry of National Education, 2003). Intelligence, in this case, is not intelligence centered on an intellectual but contains broader meaning as provided in the Law. No. 20 of 2003 clause three relating to the national education system (Aziizu, 2015; Lesmana, 2018).

The achievement of educational goals supported by a variety of instructional support factors, including internal and external factors, namely educators, the emotional condition of students, educational tools, and the environment of teachers and students. Other supporting factors are the use of teaching materials (Nisa' et al., 2015; Panjaitan et al., 2019a) and learning media (Panjaitan et al., 2016; Panjaitan et al., 2019b; Suhana, 2010; Khosmas \& Amin, 2018; Soramiranda et al., 2016). Furthermore, Suhana (2010); Khosmas \& Amin (2018); Soramiranda et al. (2016) states that the media is one of the innovative learning aids for students so that it can quickly master the material presented so that learning objectives can achieved. Not only that, the use of creative learning media will have a positive impact not only on students' understanding of learning but also it becomes the door for success for students themselves (Novitasari, 2016; Syastra, 2015).

The learning process often uses media, including science learning. Science learning is a learning process that encourages active students to learn. The number of reading demands that must be mastered by students will affect the learning outcomes that will obtained (Narulita et al., 2017). In addition, according to Tursinawati (2016), science learning also requires students to foster an attitude of curiosity and the development of an attitude in a positive direction. One of the natural science materials in junior high school class VIII is the human blood circulation system. Based on the 2013 curriculum, the material scope of the human circulatory system consist of 5 materials, i.e. 1) components of blood, 2) human circulatory organs, 3) types of human blood circulation, 4) diseases of the human circulatory system, and 5) how to maintain the health of the human circulatory system.

Pre-research shows the average daily test scores of students from three classes is 74.4. The average daily test scores are still below the minimum completeness criteria (KKM 75) set by the school (Table 1).

Table 1. Average daily science test scores

\begin{tabular}{ccccc}
\hline \multirow{2}{*}{ No } & \multirow{2}{*}{ Kelas } & \multicolumn{3}{c}{ Nilai rata-rata ulangan harian } \\
\cline { 3 - 5 } & & UH 1 & UH 2 & UH 3 \\
\hline 1 & VIII A & 75,44 & 82,05 & 64,73 \\
2 & VIII B & 77,78 & 80,46 & 69,06 \\
3 & VIII C & 74,46 & 81,81 & 67,40 \\
4 & VIII D & 74,73 & 78,85 & 68,85 \\
5 & VIII E & 75,92 & 76,20 & 68,32 \\
\hline \multirow{2}{*}{ Rata-rata } & 75,66 & 79,87 & 67,67 \\
\hline
\end{tabular}

Student test scores on the circulatory system material known that only $24.15 \%$ of students achieved KKM (see table 1). The results of an interview on May 21, 2018, with a science subject teacher, obtained information that students had difficulty understanding the material of the circulatory system. Students have trouble recognizing the characteristics and functions of blood constituent components, types of blood circulation, as well as the features and functions of human blood vessels. In addition, when teaching and learning activities, the teacher explains the material guided by the textbook, but the availability of the handbook is minimal. The results of observations made by researchers on Monday, May 21, 2018, also found that learning is still a teacher center approach. That causes the student to be less active. The low level of activity is indicated by students who do not pay attention to the teacher's explanation in front of the class, and there are busy themselves. Attention to the teacher only given by students who sit in the front. Table 1 states that the material of the human circulatory system is difficult, and students lack this material. It is in line with research conducted by Fajar (2016) at SMP Negeri 3 Rambat, which stated that as many as $70 \%$ of students did not reach the KKM on human circulatory system material.

Comics are visual media that can attract children because they can see pictures and read dialogues from the characters in comics. It is consistent with the contents of the study by Panjaitan et al. (2016); Panjaitan et al. (2019b), which states that comics consist of images, text, story, and color. Daryanto (2010) also says that the 


\section{Effectiveness of Comics on Student Learning Outcomes}

advantage of comics is that the presentation contains visual elements; comics also include stories that can be strongly remembered by the readers. Visualized expression keeps the reader emotionally involved so the reader will continue to read through to completion.

Panjaitan et al. (2019b) state that comics are examples of learning media that have many advantages, one of which is to entertain readers. In addition, Mutoharoh et al. (2012); Survia et al. (2016) also states that the use of comics in the learning process can stimulate student motivation and interest in a subject that is considered difficult to understand, encourage discussion activities, build understanding, and extend memory. The use of comics in learning human circulatory system material is expected to help improve students' knowledge of the content being studied. That is because, in the comic, it describes the processes that occur in real situations or processes that are often experienced in daily life. The material contained in this comic explains the whole story, followed by illustrations of figures and characters to make it easier for students to understand the purpose of the content thoroughly.

\section{Research Methods}

This research is quantitative. The study used quasi-experimental research with a nonequivalent control group design. The subjects of this study were students of eight grades. Referring to Sugiyono (2014), the sampling technique used was an intact group.

The research procedure consisted of the preparation, implementation, and reporting stages. In the preparatory phase includes 1) preliminary observations to observe the teaching and learning process in schools and get data in the form of science learning outcomes for students in grade 8 during the initial semester; 2) conducting library studies related to comic learning media; 3) analyzing the 8th-grade of the junior high school science curriculum in the second semester and checking the material of the human circulatory system; 4) compile learning tools in the form of lesson plans, comics, and research instruments in the way of pre-test and post-test, questions grid, and scoring guidelines; 5) validating the learning tools and research instruments; 6) revise the results of the validation; 7) testing devices outside the experimental and control classes; 8) analysis of instrument trials using validity, reliability, difficulty levels, and differentiation analysis; and 8) determine the research schedule. Activities at the implementation stage are 1) giving pre-test to research subjects, scoring pre-test, and analyzing it; 2) giving treatment to the research sample by implementing the learning process using comics in the experimental class and carrying out the learning process by using power points in the control class; 3) provide a post-test on the innovative class and the control class to determine learning outcomes; 4) giving a score and analyzing the post-test. The last stage is the reporting stage, the activities carried out include 1) analysis and processing of data obtained from research results; 2) calculate the value of the effect size (ES) to measure the effectiveness of learning; 3) interpreting and summarizing research data, and 4) completing research reports.

\section{Result and Discussion}

Comics are one of the visual media that can be used in learning (Panjaitan et al., 2016; Panjaitan et al., 2019b). The results of previous studies indicate that education using comics has a positive effect on students' motivation and interest in learning the material. In addition, comics make difficult material to be understood easier. Students become comfortable to discuss the content in comics so that the material can last a long time in students' memories.

This study aims to determine the effectiveness of comics on student learning outcomes. Measurement of students' initial abilities in the experimental class and control class is done by analyzing the results of the pre-test data. The results show that the fundamental skills of students in the experiment class and the control class are the same (see table 2). Furthermore, the results of the post-test showed that there were differences in student learning outcomes between the experimental class and the control class. The average pre-test and post-test are presented in Table 2

Table 2. Obtaining an average score of students on the Circulatory System Material

\begin{tabular}{lrrrr}
\hline \multirow{2}{*}{ Class } & \multicolumn{2}{c}{ Pre-test } & \multicolumn{2}{c}{ Post-Test } \\
\cline { 2 - 5 } & $\overline{\boldsymbol{X}}$ & SD & $\overline{\boldsymbol{X}}$ & SD \\
\hline Experiment & 8.32 & 1.99 & 15.29 & 1.64 \\
Control & 8.52 & 2.01 & 11.90 & 2.17 \\
\hline
\end{tabular}

The learning process using comics in the experimental class gives a higher average post-test compared to the control class taught using PowerPoint media (see table 2). According to 


\section{Panjaitan, Ningsih, \& Novi}

Daryanto (2010), Mutoharoh et al. (2012), the use of comics in a learning process has a positive impact on the learning process because it can motivate students to learn, even though the material is considered difficult by students. The media can increase discussion activities, build understanding, and improve student memory. In addition, the advantage of using comics as a medium for learning is the presentation that contains visual elements. Siahaan (2006) states that most junior high school students have a visual learning style. The presentation of material through reading will make the reader more emotionally involved through visualized expression and makes the reader will continue reading until the end.

The learning process in this study took place during two meetings in each class. There are three stages of learning activities in the experimental class and the control class, namely the preliminary, core, and closing stages. It is in line with Suwito (2017), which states educators need to pay attention to several things in the implementation of learning, including the introduction, core, and closing activities.

In the preliminary stage, the teacher opens learning by giving apperception, which aims to explore students' fundamental knowledge related to the material to be learned. According to Sudrajat (2007), preliminary activities are the initial activities carried out in learning with the aim to increase motivation and focus the attention of students to participate actively in the learning process. Next, in the core activities, the teacher explains the material to be learned. According to Sudrajat (2007), core activities are aimed at achieving basic competencies. This activity is carried out interactively and motivates students to participate actively in the learning process. The learning process in the experimental class is the delivery of material by the teacher only in the form of discussion topics using concept maps. Then, each student is given a circulatory system comic and is asked to read and record important things contained in the comic for 20 minutes. This process aims to make students understand the material arranged in the form of stories in comics. In accordance with Purwanto \& Rizki (2015), reading is a process to get the main meaning or idea of reading. One must involve working experience and knowledge in the reading process to master its contents. After reading, the teacher asks students to give feedback on the contents, the pictures, the explanations, the language, or the material in the comics that is not understood by students. Conversely, in the control class, the delivery of material is done by the teacher himself with the help of PowerPoint media for 25 minutes. After explaining the material, the teacher allows students to ask questions about the material that is poorly understood.

After receiving the delivery of material, students in groups are asked to discuss working on students' worksheets. Discussion activities students will get the opportunity to exchange ideas and opinions in solving problems that exist in the worksheet. The discussion activity aims to activate students during learning, and Puspitorini et al. (2014) said that the discussion had a positive impact because it could increase student learning outcomes. Each group presented the results of their discussion and obtained feedback.

Sudrajat (2007) states that the closing activity is an activity carried out to end the learning activity by summarizing or drawing conclusions, as well as providing assessment and reflection, feedback, and follow-up. The closing activity is carried out by the teacher, inviting students to come together to conclude what they have learned. The teacher gives evaluation questions to students to test their understanding of the material they have learned.

A comparison of student learning outcomes of the experimental class with the control class can be seen from the percentage of student learning outcomes achieved based on learning objectives. The results showed that in the first learning objective, the learning outcomes of the experimental class students were higher than the control class (see table 3). The percentage of the experimental class was higher than the control class because, in the experimental class, the material about blood components was conveyed with a simple and flowing comic storyline that used interesting images. Not only that, through reading comics while working on student worksheets makes students indirectly reunderstand the material about blood components. However, question number 18 is lower than the control class. The indicator about number 18 is that students can distinguish white blood cells based on the presence or absence of granules. In the experimental class, this material has been written in the comics with clear pictures and explanations. It is causing students not to understand the concept of the material and the lack of emphasis by the teacher when delivering this material.

If students already understand the concepts of the material well, then students can answer the questions correctly. Susanto (2013) states that understanding is not merely knowing or recalling experiences and then producing what has been 


\section{Effectiveness of Comics on Student Learning Outcomes}

learned. However, students are required to understand and be able to provide adequate illustrations, examples, and explanations. In the second learning objective, the average percentage experimental class is lower than the control class. The low percentage of experiment class is also due to the lack of emphasis by the teacher when explaining the material, especially on the concept

Table 3. Percentage of the results of the post-test students of the Experiment Group and the Control Group

\begin{tabular}{|c|c|c|c|c|c|c|}
\hline \multirow[t]{2}{*}{ No } & \multirow[t]{2}{*}{ Learning Objectives } & \multirow{2}{*}{$\begin{array}{l}\text { No } \\
\text { Items }\end{array}$} & \multicolumn{2}{|c|}{$\begin{array}{c}\text { Percentage of Correct } \\
\text { Answers from Experiment } \\
\text { Class } \\
\end{array}$} & \multicolumn{2}{|c|}{$\begin{array}{c}\text { Percentage of Correct Answers from } \\
\text { Control Class }\end{array}$} \\
\hline & & & $\begin{array}{c}\text { Per Items } \\
(\%)\end{array}$ & Average $(\%)$ & $\begin{array}{c}\text { Per items } \\
(\%)\end{array}$ & Average (\%) \\
\hline \multirow{5}{*}{1} & \multirow{5}{*}{ Explain the components of blood } & 16 & $77,41 \%$ & & $54,84 \%$ & \multirow{5}{*}{41,29} \\
\hline & & 17 & $38,70 \%$ & & $6,45 \%$ & \\
\hline & & 18 & $45,16 \%$ & 67,74 & $54,84 \%$ & \\
\hline & & 19 & $96,77 \%$ & & $51,61 \%$ & \\
\hline & & 20 & $80,64 \%$ & & $38,70 \%$ & \\
\hline \multirow{4}{*}{2} & \multirow{4}{*}{$\begin{array}{l}\text { Describe the organs in the circulatory } \\
\text { system }\end{array}$} & 9 & 93,55 & & 93,55 & \multirow{4}{*}{66,13} \\
\hline & & 10 & 80,64 & & 67,74 & \\
\hline & & 11 & 54,83 & 64,51 & 93,55 & \\
\hline & & 12 & 29,03 & & 9,68 & \\
\hline \multirow{3}{*}{3} & \multirow{3}{*}{ Explain the mechanism of blood clotting } & 13 & 83,87 & & 48,39 & \multirow{3}{*}{41,97} \\
\hline & & 14 & 54,83 & 70,96 & 45,16 & \\
\hline & & 15 & 74,19 & & 32,35 & \\
\hline \multirow[t]{3}{*}{4} & \multirow{3}{*}{$\begin{array}{l}\text { Differentiating the mechanism of the } \\
\text { human circulatory system }\end{array}$} & 6 & 45,16 & 79,60 & 12,9 & \multirow[t]{3}{*}{43,00} \\
\hline & & 7 & 93,55 & & 32,25 & \\
\hline & & 8 & 100,00 & & 83,87 & \\
\hline \multirow{3}{*}{5} & \multirow{3}{*}{$\begin{array}{l}\text { Explain diseases of the circulatory } \\
\text { system }\end{array}$} & 3 & 100,00 & & 96,77 & \multirow{3}{*}{92,47} \\
\hline & & 4 & 96,77 & 95,70 & 83,87 & \\
\hline & & 5 & 90,32 & & 96,77 & \\
\hline \multirow[b]{2}{*}{6} & \multirow{2}{*}{$\begin{array}{l}\text { Explain a healthy lifestyle to maintain a } \\
\text { healthy circulatory system }\end{array}$} & 1 & 96,77 & & 93,55 & \multirow[b]{2}{*}{93,55} \\
\hline & & 2 & 96,77 & 96,77 & 93,35 & \\
\hline \multicolumn{3}{|c|}{ Average } & \multicolumn{2}{|c|}{$79,21 \%$} & \multicolumn{2}{|c|}{$62,57 \%$} \\
\hline
\end{tabular}

of completeness in learning objectives in the

The third and fourth learning objectives, the average percentage of student achievement in the experimental class, is higher (see table 3), because, in the experimental class, the presentation of the material is by displaying a scheme containing information with attractive colors. It is assumed that providing information in this color makes it easy for students to remember and understand the material. Sujarwo \& Oktaviana (2017) states that the provision of color can be an important visual experience for humans and serves as a powerful information channel for the human cognitive system. In addition, color also has a significant role in improving memory performance.

The fifth learning objective is "explaining the disease in the circulatory system," the average percentage of student achievement in the experimental class is higher than the control class (see table 3). The material on this learning objective is explained through stories and drawings in comics. Stories and images will attract students of cardiac chambers.

to read and easy to remember. It is supported by Untari \& Saputra (2015), which states that the combination of language and images displayed through certain scenes can help strengthen and clarify the purpose of the contents of the comic. Unlike in the control class, the names of these diseases were only mentioned by the teacher. However, in problem number 5, the experiment class obtained a lower percentage of completeness than the control class (see table 3). A low percentage (experiment class) is assumed to be due to the lack of student understanding of the entire contents of the comic.

The sixth learning objective is to explain a healthy lifestyle to maintain a healthy circulatory system. The average percentage of student learning achievement in the experiment class is higher because, in the experiment class, the material for a healthy lifestyle to maintain the health of the circulatory system is accompanied by interesting and supportive images. In contrast, in the control class, there are no images displayed in the 
PowerPoint. In item number 1 with the question indicator, determine the right effort to treat the circulatory system disease obtained the percentage of completeness of the experimental class the same as the control class. It is because the material asked about this question is quite easy to remember. Students gain the same understanding of the efforts that can be made to maintain the health of the circulatory system either through comics or through teacher explanations through power points.

The effect size of this study was 1.56 . According to Sutrisno (2010), if the effect size is 1.56 , it is classified in the high category. With the effect size value, the comic media gives an effect of $44.06 \%$ on student learning outcomes. It shows that comics play an important role in delivering material simply and easily understood. IPA concepts can be presented interestingly with pictures and colored schemes in comics. Science comics need to be developed to make it easier for students to learn science concepts.

\section{Conclusion}

Learning with comics can improve students' understanding of the material of the circulatory system with an effect size of 1.56 . That shows that comics are effectively used as learning media in science material. Furthermore, it is recommended to develop comic media to learn other material that contains science.

\section{References}

Aziizu, B. Y. A. (2015). Tujuan Besar Pendidikan adalah Tindakan. Prosiding: $K S$ \& Riset $P K M$, 2(2), 295-300. Retrieved from http:// jurnal.unpad.ac.id >prosiding $>$ article >download.

Daryanto. (2010). Media Pembelajaran. Yogyakarta: Gavarmedia.

Departemen Pendidikan Nasional. (2003). Undangundang RI. No.20 tahun 2003. Retrieved from https:// kelembagaan.ristekdikti.go.id.

Fajar, N. (2016). Proses Pembelajaran Biologi Pada Materi Sistem Peredaran Darah Manusia di Kelas VIII SMP Negeri 3 Rambatan. Jurnal Ilmu Pendidikan, 19(2), 103-114. Retrieved from http://ppjp .ac.id/journal /article view.

Khosmas, A. \& Amin, M. (2018). Penerapan Media LCD Proyektor Pada Pembelajaran
IPS Kelas VIII A SMP Islam AlAsy'ariyyah Pontianak. Jurnal Untan, 7(12), 5-10. Retrieved from http://jurnal .untan.ac.id/index.php/jpdpb/ article /downlod/23803/18678.

Lesmana, D. (2018). Kandungan Nilai Dalam Tujuan Pendidikan Nasional (Core Ethical Values). Jurnal Pendidikan, 17(1), 212-224. http:// doi.org/10.15408/kordinat.v17i1.8 103.

Munirah. (2015). Sistem Pendidikan di Indonesia: antara keinginan dan realita. Jurnal Pendidikan, 2(2), 233-245. Retrieved from http:// journal.uin-alauddin.ac.id`index.ph praulad unararticle download.

Mutoharoh, Razali, \& Nasbey, H. (2012). Pengembangan Komik sebagai Media Sebagai Media Pembelajaran Fisika untuk Siswa SMA. Seminar Nasional Fisika, 1(2), 126-131. Retrieved from http://journal.unj. ac.id.

Nisa', A, Sudarmin \& Samini. (2015). Efektivitas penggunaan modul terintegrasi etnosains dalam pembelajaran berbasis masalah untuk meningkatkan literasi sains siswa, Unnes Science Education Journal, 4(3), 1049-1056. Retrieved from https://journal.unnes.ac.id/sju/index.php/usej /article/view/8860

Narulita, E., Prihatin, J., \& Agatha, N. D. (2017). Pengembangan Buku Komik Pokok Bahasan Sistem Peredaran Darah. Jurnal Bioedukatika, 5(2), 67-83. Retri eved from http://journal.uad.ac. id/index.php/BIOEDUKATIKA.

Novitasari, D. (2016). Pengaruh Penggunaan Multimedia Interaktif Terhadap Kemampuan Pemahaman Konsep Matematis Siswa. Jurnal Pendidikan Matematika \& Matematika, 2(2), 8-18. https://doi .org/10.24853/fbc. $2.2 .8-18$

Panjaitan, R. G. P., Sari, D. P., Wahyuni, E.S., \& Shidiq, G.A. (2019a). Feasibility of Human Excretory System Module in Biology Learning. Jurnal Penelitian dan Pembelajaran IPA, 5(1), 84-93. https://dx.doi.org./10.30870/jppi. v5i1.3894.

Panjaitan, R. G. P., Lijana, \& Wahyuni, E. S. $(2019 b)$. The Use Of Comic As a Learning 


\section{Effectiveness of Comics on Student Learning Outcomes}

Medium For Ecology. Unnes Science Education Journal, 8(1), 41-45. https://doi.org./10.152 94/usej.v8i1. 23194.

Panjaitan, R. G. P., Savitri, E., \& Titin (2016). Pengembangan Media E-Comic Bilingual Sub Materi Saluran dan Kelenjar Pencernaan. Unnes science education journal, 5(3), 1379-1387. https://doi.org/10.1529 4/usej.v5i3.13167.

Purwanto, Y., \& Rizki, S. (2015). Pengembangan Bahan Ajar Berbasis Kontekstual pada Materi Himpunan Berbantu Video Pembelajaran. Jurnal Pendidikan Matematika, 4(1), 67-77. Retrieved from http://ojs.fkip.ummetro.ac.id.

Puspitorini, R., Prodjosusanto, Bambang, \& Jumadi. (2014). Penggunaan Media Komik dalam Pembelajaran IPA untuk Mening katkan Motivasi dan Hasil Belajar Kognitif dan Afektif. Jurnal Cakrawala Pendidikan, 33(3), 413-420. https:// doi.org/1021831/cp.v3 i3.2385.

Siahaan, P. (2006). Jenis Gaya Belajar Siswa SMP. Jurnal Pengajaran MIPA, 8(2), 11-17. https://dx.doi. $\quad$ org $\quad / 10.18269$. jpmipa.v8i2.330.

Soramiranda, N., Ningsih, K., \& Panjaitan, R. G. P. (2016). Efektivitas Penggunaan Media Powerpoint Disertai Kartu Bergambar Terhadap Hasil Belajar Siswa Pada Materi Klasifikasi Makhluk Hidup Di Kelas VII SMPN 2 Ketapang. Jurnal Lentera Sains, 6(2), 77-83. https://doi.org/10.15294/usej.v5i3. 13167.

Sudrajat, A. (2007). Pengembangan Kegiatan Pembela jaran Mapel PAI. Retrieved from http://staffnew .uny.ac.id/upload/131862252/pengabdian/K EGIATAN+PEMBELAJA RAN+PAI + SMP.pdf.

Sugiyono. (2014). Metode Penelitian Pendidikan Pendekatan (Kuantitatif Kualitatif dan $R \& D)$. Bandung: Alfabeta.

Suhana, C. (2010). Konsep Strategi Pembelajaran. Bandung: PT Refika Aditama.

Sujarwo, S. \& Oktaviana, R. (2017). Pengaruh Warna terhadap Short Term Memory pada Siswa Kelas VIII SMPN 37 Palembang.
Jurnal Psikologis Islami, 3(1), 33-42. https://doi.org.10.19109.psikis.v3 i1.1391.

Survia, Panjaitan, R. G. P., \& Titin (2016). Pembuatan Media E- Komik Pada Sub Materi Zat Aditif. Jurnal Pendidikan dan Pembelajaran Untan, 5(7), 1-11. Retrieved from https://www.neliti.com/publiccatio ns/217236/pembuatan-media-ekom ik-padasub-materi-zat-aditif.

Sutrisno, L. (2010). Effect Size. Diambil dari http://www.sribd.com.

Susanto. (2013). Pengaruh Media Komik terhadap Hasil Belajar Matematika Siswa pada Konsep Faktor dan Kelipatan. Jurnal Pendidikan Matematika, 2(2), 2-10. Retrieved from http://repository.uinjkt.acid/ bitstream/12345678.pdf.

Suwito, A. (2017). Pendekatan Parade untuk Meningkatkan Aktivitas dan Hasil Belajar Peserta Didik Tentang Materi Sistem Pemerintahan Melalui Pemanfaatan Media Voucher pada Kelas XII IPS 2 SMA Negeri 1 Lasem. Jurnal Ilmiah CIVIS, 5(2), 843854. Retrieved from http://journal.upgris.ac.id.

Syastra, M. T. (2015). Pemanfaatan Media Pembelajaran Berbasis Teknologi Informasi Bagi Siswa Kelas X SMA Ananda Batam. CBIS Jurnal, 3(2), 78-90. Retrieved from http://ejour nal.upbatam.ac.id index.php > cbis $>$ article $>$ download.

Tursinawati. (2016). Penguasaan Konsep Hakikat SAINS dalam Pelaksanaan Percobaan pada Pembelajaran IPA di SDN Kota Banda Aceh. Jurnal Pesona Dasar, 2(4), 72-84. Retrieved from http://jurnal.unsy iah.ac.id.

Untari, M. F. A. \& Saputra, A. A. (2016). Keefektifan Media Komik Terhadap Kemampuan Membaca Pemahaman pada Siswa Kelas IV SD. Jurnal Mimbar Sekolah Dasar, 3(1), 29-39. https://doi.org/10.17509/mimbar-s d.v3i1.2354

Yusuf, W. F. (2018). Implementasi Kurikulum 2013 (K-13) Pada Mata Pelajaran Pendidikan Agama Islam Sekolah Dasar (SD). Jurnal Pendidikan Agama Islam, 3(2), 263-277. Retrieved from http://jurnal. yudharta.ac.id. 